\title{
Growth Response and Haematological Indices of Hybrid Catfish Fingerlings Fed Varying Inclusion Levels of Fermented Sword Bean (Canavalia Gladiata) Seed Meal in a Concrete Tank
}

\author{
G. G. Bake $^{1^{*}}$, R. Theophilus ${ }^{1}$, A. Abdullahi ${ }^{2}$, D.C. Nwangwu ${ }^{3}$ And M.H Aliyu ${ }^{4}$ \\ ${ }^{I}$ Department of Water Resources, Aquaculture and Fisheries Technology, School of Agric and Agric \\ Technology, Federal University of Technology Minna, Niger state, Nigeria. \\ ${ }^{2}$ Department of Aquaculture and Fisheries, Faculty of Agriculture, University of Ilorin, PMB 1515 Ilorin, \\ Kwara State-Nigeria. \\ ${ }^{3}$ National Institute for Freshwater Fisheries Research (NIFFR), P.M.B. 6006, New Bussa, Niger State, Nigeria. \\ ${ }^{4}$ Department of Agricultural Science Education, Niger State College of Education P.M.B. 39 Minna Niger State, \\ Nigeria.
}

*Corresponding Author: G G Bake, Department of Water Resources, Aquaculture and Fisheries Technology, School of Agric and Agric Technology, Federal University of Technology Minna, Niger state, Nigeria.

\begin{abstract}
This study investigates the use of fermented Canavalia gladiata seed meal (FCGSM) in practical diets of hybrid catfish - Hetero-clarias. A total of 300 fish (initial mean weight $1.64-1.67 \mathrm{~g}$ ) were fed five isonitrogenous and isolipidic diets formulated at $40 \%$ crude protein and $9.5 \%$ lipid containing different graded levels of FCGM to replace Clupeid (Sierrathrissa leonensis) fishmeal. for 70 days. Diets were designated as D1 (0\% inclusion), D2 (15\% inclusion), D3 (25\% inclusion), D4 (35\% inclusion) and D5 (45\% inclusion). 20 fish per hapa were accommodated in fifteen net hapa $(0.5 \times 0.5 \times 1 \mathrm{~m})$ suspended in two outdoor concrete ponds $(8 m \times 5 m x 1.5 m)$ with the aid of kuralon twine tied to plastic poles, the concrete ponds were filled to 5/6 of its volume (40m3) with filtered and dechlorinated tap water. The fish were fed manually at 5\% body weight three times daily. The results showed that the fish fed Fish fed D4 diet had the highest significant $(P<0.05)$ values in all growth parameters measured while, those fed with D5 had the lowest value but was not significantly $(P>0.05)$ different from those fed D1, D2 and D3. There was no significant different in the percentage survival among all the fish fed the experimental diets. The feed utilization followed the same pattern as the growth parameters. The proximate composition results revealed that carcass lipid increased with the proportional increase in the inclusion level of the FCGM in the diet. It could be concluded that 35\% inclusion of FCGM meals improved growth performance and nutrient utilization of hybrid catfish without any adverse effect on their health status, suggesting that FCGM can be could be a suitable ingredient in the diet of hybrid catfish.
\end{abstract}

Keywords: Hybrid catfish; Growth performance; Canavalia gladiata; Fermentation; Hapas.

\section{INTRODUCTION}

Intensive fish production involves the input of supplementary and complete feeds which often represent a large part of production costs (Chen and Tsai, 1994). Fish require proteins, fats, carbohydrates in addition to vitamins and minerals in appropriate proportions to enhance fast growth, optimum health and harvest (Falaye, 1988; Ufodike et al., 2011). Protein assumes a very important place in bodybuilding and replenishing (Davies et al., 1997), and therefore, must be considered as a critical or limiting nutrient. The most common protein source used in aqua feed is the fishmeal and largely derived from small oily fish caught by so-called "industrial fisheries". Due to the everincreasing demand for fish meal and fish oil for farmed fish and crustaceans, there's growing concern on over-exploitation of capture fishery derived fish products for aquaculture. This contributes to depletion of certain types of fisheries with negative concomitant effects on other wild fish stock hence unsustainable for aquaculture (Naylor et al., 2000).

Among several other alternatives that have been examined, plant protein sources happen to have the most promising potential (Abdelghany, 2004; Ingweye et al., 2010). These plant protein sources 
include soybean, groundnut, sunflower, rapeseed, and cottonseed cake. However, despite their usefulness, these ingredients are scarce and expensive due to the high demand for livestock production and other industrial production sectors. Moreover, their cultivation generally requires a high use of inputs and energy subsidies (Francis et al., 2002). This makes them unaffordable, unsustainable and sometimes conflicts with food security interests, particularly among resource-poor farmers in the developing nations. Therefore, research interest has been redirected toward nonconventional protein sources which could be easily available and cost-effective without compromising the growth of the fish. One of such non-conventional sources which is rich in protein and is envisaged would probably be capable of substituting for the expensive ingredient in the fish diet is Sword Bean Seed. (NAS, 1979; Udedibie, 1990; Akinmutimi et al., 2004).

Sword Bean (Canivalia gladiata) is a perennial or annual, fast-growing, heavily producing, climbing vegetable. It is widely cultivated in the humid tropics of South and Southeast Asia but worldwide it remains a minor vegetable due to its toxicity when eaten uncooked. Young green pods and leaves are eaten sparingly as a cooked vegetable. This crop is most useful as a cover crop that fixes nitrogen and as a drought tolerant green manure (Ekanayake et al., 2000). The vines and seeds, good sources of protein and starch, can be fed to livestock but only in small amounts. It thrives well on poor soils where most crops fail due to excellent adaptability to extreme climatic conditions. It yields about $4600 \mathrm{~kg}$ seeds per hectare. Research and laboratory analysis have shown that Sword beans are good sources of protein and a complementary level of starch. The protein composition could range between 22- $35 \%$ with good amino acid profile, rarely edible by man and of no industrial usage (Udedibie, 1990; Akinmutimi and Abasiekong, 1997; Akinmutimi et al., 2004). The seeds contain a considerable amount of linoleic acid (18:2 n-6), they like Jack beans are rich in oleic acid (18:1n-9), with high Palmitic acid (16:0) level, and very low in both stearic acid (18:0) and myristic acid (14:0) (Ogunji et al., 2003). The anti-nutritional factor evaluation of Canavalia gladiata seed flour indicated a high amount of phytic acid, trypsin inhibitor and an a-amylase inhibitor which decreased with any processing technique employed (Ekanayake et al., 2001). The results of animal feeding experiments with raw and processed samples of mature seed flour also indicated the seeds to have low net protein utilization (NPU) (Ekanayake et al., 2000).

It is very expedient to remove most of the undesirable components to improve the nutritional quality of meals or diets and to utilize their potential as animal feeds effectively. Several conventional food processing methods, such as germination (Nnanna et al., 1990), soaking (Vidal-Valverde et al., 1994), cooking (Urbano et al., 1995), fermentation (Yamamato et al., 1992 Bake et al., 2014) and gamma irradiation (Abu-Tarbonsh, 1998) are known to reduce antinutritional factors effectively and to upgrade the nutritional quality of feeds of plant origin. However, some of these treatments affect the sensory characteristics of the final product adversely. Of all the feed processing techniques, fermentation method is the most utilized especially in the developing countries. This may be attributed to its food safety and preservation power viz as rapid drop of $\mathrm{pH}$ close to 4, inhibition of enteropathic bacteria growth and its ability to reduce anti-nutritional factors in an ingredient to the barest level. It also improves and increases digestibility of products as well as boost the nutritional value of the ingredient or diet. This fermentation process provides a promising future for plantderived ingredients for sustainable aquaculture.

Haematological studies in fish nutrition is gaining more attention of fisheries researchers due to its importance in monitoring the physiological condition and health status of the cultured fish (Hrubec et al., 2000). It serves mainly for diagnostic purpose hence can be used to appraise the suitability of feeds and feed mixture pellets, to examine the effect of stress situation etc. (Svobodova et al., 1991). Changes in haematology of fish in response to stressing agents are indicators of the stressful stage of fish, giving vital information to control any unfavorable condition that may affect the health status of the fish. (Bello-Olusoji et al., 2006). Furthermore, the knowledge of haematological characteristics of the fish is important in toxicological studies and its implication on final consumers which is the man. In culture fisheries, these studies are usually associated with the feed input. The red blood cells count (RBC), haematocrit (PCV) and haemoglobin (Hb) concentration vary with diet and strain as well as temperature, the season of the year and nutritional status of the fish (Barnhart, 1969).

Though sword bean seed is in abundant especially in the tropics, much work have not been carried out on its utilization as a potential ingredient in the diet of hybrid catfish fingerlings and its subsequent 
impact on the haematological indices of the fish. It is in the light of this that this study was carried out with the main objective to investigate among other things the growth response, nutrient utilization and hematological indices of hybrid catfish fingerlings fed varying inclusion levels of fermented Canavlia gladiate (Sword bean) seed meal in a concrete tank.

\section{Materials AND Methods}

\subsection{Ingredients and diet formulation}

\subsubsection{Soybean Meal (SBM) and Fishmeal (FM)}

Raw soybean was purchased from the Bosso market, Minna, Niger state, Nigeria. The soybean was processed by toasting the soybean in frying pan until the colour changes to golden brown and allowed to cool before milling with the aid of a grinding machine while the fishmeal used in this experiment was obtained from the Musgola Fish Farm, along Bosso estate road, Minna, Niger state.

\subsubsection{Fermented Canivalia gladinata seed meal (FCGM)}

Raw sword beans (Canivalia gladinata) was collected from a local farmer in Minna metropolis. It was weighed raw, sieved to remove dirt. The fermentation of the seeds was carried out by mixing the Canivalia gladinata seed with water in the ratio 1:2;0.25ml of cultured Aspergillus niger which was collected from the Department of Microbiology laboratory of Federal University of Technology Minna, was pipette and mixed with the water. The mixture was packed in a plastic container, firmly sealed with cotton wool before being kept in a room at ambient temperature of $25^{\circ} \mathrm{C}$. The sample was allowed to ferment for five days. The fermented sample was then washed and spread on a polythene sheet in a room and dried for six (6) days up to about $90 \%$ of the dry matter. The seed was grinded into powder using hammer mill. All the ingredients were separately milled and mixed with warm water to form consistent dough, which was then pelleted, sun-dried, packed in polyethylene bags and stored. The feed composition table is shown in Table 3

\subsubsection{Experimental diets}

Based on the nutritional requirements of Catfish fingerlings (NRC 1993), five isonitrogenous and isolipidic diets were formulated at $40 \%$ protein and $9.5 \%$ lipids, containing $0-45 \%$ FCGSM at different levels of inclusion.

\subsubsection{Experimental conditions and fish rearing}

The experimental fish, hybrid of C. gariepinus fingerlings, with an initial mean weight of (1.64 $1.67 \mathrm{~g}$ ) were purchased from Tagwai fish hatchery of Ministry of Livestock and Fisheries development Minna, Niger state. The fish were transferred in a well-oxygenated water plastic container from the hatchery to the Department of Water Resources, Aquaculture and Fisheries Technology experimental fish farm, Federal University of Technology, Minna Bosso campus, where the feeding trial was conducted. Upon arrival they were acclimatized in a transitional tank in the farm for four days and were fed commercial feed (Coppens ${ }^{\circledR}$ feed) at $40 \%$ crude protein once a day before the experiment commenced. The fish were subsequently fed with $40 \%$ iso-nitrogenous diet and $9.5 \%$ lipid, containing different inclusion level of FCGM, designated as D1 (0\% inclusion), D2 (15\% inclusion), D3 (25\% inclusion), D4 (35\% inclusion), D5 (45\% inclusion) for 70 days. Fifteen net hapa $(0.5 \times 0.5 \times 1 \mathrm{~m})$ were suspended in two outdoor concrete tanks $(8 \mathrm{~m} \times 5 \mathrm{mx} 1.5 \mathrm{~m})$ with the aid of kuralon twine tied to plastic poles. The concrete tanks were filled to $5 / 6$ of its volume $(40 \mathrm{~m} 3)$ with filtered and dechlorinated tap water, 20 fish were accommodated in each hapa. Each treatment was randomly allocated to three hapa, Photoperiod depends on the natural light, and water temperature was monitored daily. The water quality parameters in the system were monitored and recorded weekly. Two replicates of each treatment using 20 fish per hapa were reared on each of the five diets. The feed was manually administered and the fish were fed to 5\% body weight three times daily at 09:00 am, 12:00pm and 16:00pm. Feeding rate was subsequently adjusted according to their growth rates per hapa. The uneaten feed was siphoned out of the hapa 30 minutes after each feeding period while collection of faeces samples was carried out for 2 weeks by siphoning, using a $2 \mathrm{~cm}$ diameter hose, three hours after feeding and the fish were denied feed $24 \mathrm{~h}$ prior to sampling. Five fish were randomly sampled on weekly basis, and weights were measured using a digital electronic weighing balance (CITIZEN MP-300) model. 


\subsubsection{Biochemical Analysis}

About 10 fish initial sample and 5 of final samples from each hapa were pooled separately and then homogenized using laboratory mortar and pestle. The major ingredient used for the diet; the formulated diet and the fish body samples were subjected to chemical analysis. The proximate composition analysis was determined according to AOAC procedures (2000). Moisture content was determined by drying samples at $105 \pm 2^{\circ} \mathrm{C}$ until a constant weight was obtained. Dried samples were used for determination of crude fat, protein and Ash contents. Crude fat was measured by solvent extraction method in a Soxhlet system where n-hexane was used as solvent. Crude protein content was calculated by using nitrogen content obtained by Kjeldahl method. A conversion factor of 6.25 was used for calculation of protein content according to AOAC (2000). Anti-nutritional factors of the seeds; tannins and trypsin inhibitor activity (TIA) were analyzed by modifying the procedures of AOAC (1984). Phytic acid was determined by the method of Latta and Eskin (1980).

\subsubsection{Acid Insoluble Ash (AIA) Analysis}

AIA analyses were carried out on the diets and faeces. AIA was obtained by adding $25 \mathrm{ml}$ of $10 \%$ $\mathrm{HCl}$ to the weighed ash content of a sample. This was covered with a water-glass and boiled gently over a low flame for five minutes. This was then filtered using ash less filters and washed with hot distilled water. The residue from the filter was returned to the crucible and ignited until it was carbon free after which it was weighed. Percentage AIA was calculated as:

$\%$ AIA $=($ Weight of AIA $/$ Weight of Ash $) \times 100$

\subsubsection{Determination of digestibility coefficient}

The determination of the protein and lipid digestibility coefficient was done according to Jimoh et al., (2010) which was calculated based on the percentage of AIA in feed and in faeces and the percentage of nutrient on diets and faeces.

Apparent protein digestibility $(\%)=100-(($ AIA in diet $(\%) /$ AIA in faeces $(\%)) \times(\mathrm{N}$ in faeces $(\%) /$ $\mathrm{N}$ in $\operatorname{diet}(\%)) \times 100)$

\subsubsection{Blood Collection and Haematological Analysis}

Blood samples were collected in triplicate following the procedure of Klontz and Smith (1968) and Wedemeyer and Yasutake (1977), and subsequently taken to the Laboratory of Department of Biochemistry Federal University of Technology Minna for haematological analysis. At the laboratory the clear fluid sample which is the serum was pipetted out into a clean and sterilized bottle for haematological parameters analysis (Ogbu and Okechukwu, 2001). The direct measurement of erythrocyte values (Packed cell volume PCV, Haemoglobin Hb, and Red blood cell RBC) and absolute erythrocyte indices ( $\mathrm{MCH}, \mathrm{MCV}$ and $\mathrm{MCHC}$ ) were calculated. The white blood cell and differential count (neutrophils and lymphocytes) were analysed as described by Dacie and Lewis (2001).

$\mathrm{MCV}=\mathrm{PCV} /$ Erythrocytes count $\times 10$

$\mathrm{MCH}=$ Haemoglobin/ Erythrocytes count $\times 10$

$\mathrm{MCHC}=$ Haemoglobin $/ \mathrm{PCV} \times 100$

Evaluation of Nutrient Utilization Parameters

Nutrient Utilization were analyzed in terms of Feed Efficiency (FE), Specific Growth Rate (SGR), Feed Intake (FI), Protein Efficiency Ratio (PER) and Protein Retention (PR). The following formulas were used:

Feed efficiency $(\%)=($ weight gained $(\mathrm{g}) /$ feed fed $(\mathrm{g})) \times 100$

Specific growth rate $(\%)=($ In final weight $(\mathrm{g})-$ In initial weight $(\mathrm{g}) /$ feeding period $($ day $) \times 100$

Feed intake $(\mathrm{mg} /$ fish/day) $=$ dry feed $(\mathrm{mg})$ given / number of fish / feeding period (day)

Protein efficiency ratio $=$ wet body gain $\times 100 /$ protein intake $(\mathrm{g})$

Protein retention $(\%)=$ protein gain $\times 100 /$ protein fed .

Statistical Analyses 
Growth Response and Haematological Indices of Hybrid Catfish Fingerlings Fed Varying Inclusion Levels of Fermented Sword Bean (Canavalia Gladiata) Seed Meal in a Concrete Tank

Data were analysed using one-way analysis of variance (ANOVA) using Mintab 17.0 (Stat-Soft, Inc., Oklahoma, USA). Differences between treatments were compared by Tukey's test. Level of significance was tested at $\mathrm{P}<0.05$.

\section{RESUlts}

Over the 10-week feeding period, no significant differences were observed in the water-quality indices between the experimental treatments. The water temperature ranges from $23.8-29.4^{\circ} \mathrm{C}$, Dissolved oxygen from 5.62-7.91 mg/l, $\mathrm{pH}$ from 6.38-7.64 and ammonia from 0.23-0.29 mg/l.

Table 1 shows the proximate composition of the major ingredients used in formulating the experimental diets. Fish meal has the highest crude protein and lipid content $(65.34 \%$ and $11.36 \%)$ followed by soybean meal $(43.63 \%$ and $7.00 \%)$, while the crude protein and lipid content of both the raw and fermented Canavalia gladiata meal was $(28.61 / 32.64 \%$ and 9.44 / 9.08\%) respectively. Table 2 shows the anti-nutritional factor composition of both the raw Canavalia gladiate seed meal (RCGSM) and the fermented Canavalia gladiate seed meal (FCGSM). All the anti-nutritive factors parameters measured were lower in the FCGSM ingredients as compared to the RCGSM. The feed formulation profile and the proximate composition of the experimental diets is shown in Table 3 . There were no much variations in the protein and crude lipid content among the formulated experimental diets. Table 4 Showed growth performance indices and nutrient utilization of the fish fed experimental diets. Fish fed D4 diet had the highest significant $(\mathrm{P}<0.05)$ values in FBW and WG while, those fed with D5 had the lowest value but was not significantly $(\mathrm{P}>0.05)$ different from those fed D1, D2 and D3. There was no significant different in the percentage survival among all the fish fed the experimental diets. Although fish fed D4 had the highest TFI value among all the fish fed the experimental diets there was no significant difference between fish fed D4 and those fed D1, D2, D3. Fish fed D5 had the lowest value and was significantly lower than fish fed D4 but was not significantly different from fish fed D1, D2 and D3 (P>0.05). Fish fed D4 had the highest significant FE value and was significantly different from fish fed other experimental diets $(\mathrm{P}<0.05)$, fish fed D5 had the lowest FE value but was not significantly different from fish fed D1 and D2, while fish fed D3 was significantly higher than those fed D5. The PER and PR followed the same pattern, with fish fed D4 significantly higher than the other fish fed other experimental diets $(\mathrm{P}<0.05)$. Fish fed D5 had the lowest value and was significantly lower than fish fed D1, D2 and D3, however there was no significant $(\mathrm{P}>0.05)$ different in the PER and PR values between fish fed D1, D2 and D3 The apparent digestibility coefficients of the experimental diets are displayed in Table 5, the ADC of crude protein, lipid and fiber of the experimental diets showed that except D5 which was significantly lower than other experimental diets, there was no significant difference between D1, D2, D3 and D4. Table 6 showed the proximate composition of the fish fed the experimental diets. The haematological indices composition of the initial and final groups of the fish fed with the experimental diets is given in Table 7. All the final haematological indices compositions of the fish fed experimental diets were higher than the initial. Fish fed D5 had the lowest PCV among the fish fed experimental diets and was significantly different from those fed other experimental diets $(\mathrm{P}<0.05)$. While fish fed $\mathrm{D} 3$ had the highest PCV, but was not significantly different from those fed D1, D2 and D4 (P>0.05). D5 had the highest WBC value among the fish fed all the experimental diets and was significantly different from others, while D1 had the lowest WBC value but was not significantly different from D2, D3 and D4 $(\mathrm{P}>0.05)$. There were no significant differences among treatments in values of RBC, Hb, LYMPH, $\mathrm{MCHC}, \mathrm{MCH}(\mathrm{P}>0.05)$

Table1. Proximate composition (expressed on a dry-matter basis) of the major ingredients used for the experimental diets including Raw and Fermented Canavalia gladiata seed meal (FCGM)

\begin{tabular}{|c|c|c|c|c|c|c|}
\hline Ingredients & Fishmeal & Soybean meal & Maize meal & Millet meal & RCGM & FCGM \\
\hline Proximate composition & & & & & & \\
\hline Moisture (\%) & 5.79 & 3.09 & 4.66 & 3.22 & 6.85 & 5.28 \\
\hline Crude protein $\left(\%\right.$ d.b. $\left.^{* 1}\right)$ & 65.34 & 43.63 & 9.32 & 12.9 & 28.61 & 32.64 \\
\hline Crude lipid (\% d.b. ${ }^{* 1}$ ) & 11.36 & 7.00 & 4.20 & 4.36 & 9.44 & 9.08 \\
\hline $\operatorname{Ash}\left(\%\right.$ d.b. $\left.{ }^{* 1}\right)$ & 14.34 & 8.15 & 3.22 & 2.33 & 4.56 & 2.98 \\
\hline Crude fibre $(\%$ d.b. $* 1)$ & 0.06 & 5.00 & 3.40 & 2.60 & 6.94 & 6.24 \\
\hline
\end{tabular}

${ }^{a}$ Means of two replicate analyses 
Growth Response and Haematological Indices of Hybrid Catfish Fingerlings Fed Varying Inclusion Levels of Fermented Sword Bean (Canavalia Gladiata) Seed Meal in a Concrete Tank

Table2. Effect of fermentation treatment on anti-nutritional factors in Raw and Fermented Canavalia gladiata seed meal (FCGM)

\begin{tabular}{|c|c|c|c|c|c|c|}
\hline Anti-nutritive factors & \multicolumn{2}{|c|}{ RCGM } & \multicolumn{2}{|c|}{ FCGM } & \multicolumn{2}{c|}{$\begin{array}{c}\text { (\%) decrease of anti-nutritive factors after } \\
\text { fermentation }\end{array}$} \\
\hline Phytate $(\mathrm{mg} / \mathrm{g})$ & 21.55 & 5.11 & & 76.29 & 91.23 \\
\hline Oxalate $(\mathrm{mg} / \mathrm{g})$ & 2.85 & & 0.25 & 80.00 & 80.36 & \\
\hline Tannin $(\mathrm{mg} / \mathrm{g})$ & 0.05 & & 0.01 & & \\
\hline Saponin $(\mathrm{g} / 100 \mathrm{~g})$ & 5.50 & & 1.08 & & & \\
\hline $\begin{array}{c}{ }^{a} \text { Means of two replicate } \\
\text { analyses }\end{array}$ & & & & & & \\
\hline
\end{tabular}

Table3. Formulation profile and proximate composition of experimental diets $(\mathrm{g} / \mathrm{kg})$

\begin{tabular}{|c|c|c|c|c|c|}
\hline Ingredients & D1 & D2 & D3 & D4 & D5 \\
\hline FM (Clupeid) & 577.50 & 496.90 & 443.60 & 390.50 & 337.20 \\
\hline Soybean meal & 100.00 & 100.00 & 100.00 & 100.00 & 100.00 \\
\hline Fermented sword bean meal & 0.00 & 150.00 & 250.00 & 350.00 & 450.00 \\
\hline Yellow maize & 25.00 & 25.00 & 25.00 & 25.00 & 25.00 \\
\hline Millet & 25.00 & 25.00 & 25.00 & 25.00 & 25.00 \\
\hline Starch & 20.00 & 20.00 & 20.00 & 20.00 & 20.00 \\
\hline Vitamin premix & 12.50 & 12.50 & 12.50 & 12.50 & 12.50 \\
\hline Soybean oil & 19.50 & 14.6 & 10.9 & 7.4 & 4.10 \\
\hline Mineral & 208 & 143.5 & 100.5 & 57.1 & 13.7 \\
\hline Cellulose & 12.50 & 12.50 & 12.50 & 12.50 & 12.50 \\
\hline Total & 1000.00 & 1000.00 & 1000.00 & 1000.00 & 1000.00 \\
\hline Moisture (\%) & 4.8 & 4.7 & 4.7 & 4.8 & 4.50 \\
\hline Crude protein $\left(\%\right.$ d.b. $\left.^{* 1}\right)$ & 37.1 & 37.3 & 37.5 & 37.6 & 37.4 \\
\hline Crude lipid (\% d.b. $\left.{ }^{* 1}\right)$ & 8.6 & 8.7 & 8.8 & 8.8 & 8.6 \\
\hline $\operatorname{Ash}\left(\%\right.$ d.b. $\left.{ }^{* 1}\right)$ & 9.2 & 9.3 & 9.5 & 9.7 & 9.5 \\
\hline Crude fibre (\% d.b. $* 1)$ & 6.4 & 6.4 & 6.6 & 6.7 & 6.8 \\
\hline $\operatorname{AIA}\left(\%\right.$ d.b. $\left.{ }^{* 1}\right)$ & 5.2 & 5.3 & 5.5 & 5.4 & 6.4 \\
\hline \multicolumn{6}{|c|}{$\begin{array}{l}\text { FM=Fish meal; SBM= Soybean meal; FSBM =Fermented Sword bean meal; MM= Yellow maize meal; SBC } \\
\text { Sheabutter oil }\end{array}$} \\
\hline \multicolumn{6}{|l|}{ d.b ${ }^{* 1}=$ dry basis } \\
\hline AIA $=$ Ash insoluble Ash & & & & & \\
\hline
\end{tabular}

**: Premix composition: vitamin and mineral premix (IU or $\mathrm{mg} / \mathrm{kg}$ of premix). Vitamin A: 4800 IU; Cholecalciferol (vitamin D): 2400 IU; Vitamin E: 4000 mg; Vitamin K: 800 mg; Vitamin B1: 400mg; Riboflavin: 1600 mg; Vitamin B6: 600 mg, Vitamin B12: 4 mg; Pantothenic acid: 4000 mg; Nicotinic acid: 8000mg; Folic acid: $400 \mathrm{mg}$; Biotin: $20 \mathrm{mg}$, Manganese: $22000 \mathrm{mg}$; Zinc: $22000 \mathrm{mg}$; Iron: $12000 \mathrm{mg}$; Copper: $4000 \mathrm{mg}$; Iodine: $400 \mathrm{mg}$; Selenium: $400 \mathrm{mg}$; cobalt: 4.8

Table4. Growth performances and nutrient utilization of hetero-clarias hybrid fingerling catfish fed experimental diets for 70 days.

\begin{tabular}{|c|c|c|c|c|c|c|c|c|}
\hline \multirow{2}{*}{$\begin{array}{l}\text { Dietc } \\
\text { ode }\end{array}$} & \multicolumn{2}{|c|}{ Body weight (g) } & \multirow{2}{*}{$\begin{array}{l}\text { Weight } \\
(\%)\end{array}$} & \multirow{2}{*}{$\begin{array}{c}\text { gain } \mid \begin{array}{l}\text { Survival } \\
\text { rate }(\%)\end{array}\end{array}$} & \multirow{2}{*}{$\begin{array}{l}\text { Total feec } \\
\text { intake }(\mathrm{g})\end{array}$} & \multirow{2}{*}{$\begin{array}{l}\text { Feed } \\
\text { efficiency }\end{array}$} & \multirow{2}{*}{$\begin{array}{l}\text { Protein } \\
\text { efficiency } \\
\text { ratio }\end{array}$} & \multirow{2}{*}{$\begin{array}{l}\text { Protein } \\
\text { retention }(\%)\end{array}$} \\
\hline & Initial & Final & & & & & & \\
\hline D1 & $1.65 \pm 0.54$ & $20.70 \pm 0.43$ & $138.2 \pm 15.6^{b}$ & $99.6 \pm 2.3^{\mathrm{a}}$ & $24.0 \pm 0.7^{\mathrm{ab}}$ & $0.78 \pm 0.41^{\mathrm{bc}}$ & $2.11 \pm 0.37^{b}$ & $39.42 \pm 0.42^{b}$ \\
\hline $\mathrm{D} 2$ & $1.67 \pm 0.38$ & $20.39 \pm 0.56^{b}$ & $1121.0 \pm 18.4^{\mathrm{b}}$ & $98.7 \pm 2.5^{\mathrm{a}}$ & $23.9 \pm 0.5^{\mathrm{ab}}$ & $0.78 \pm 0.62^{\mathrm{bc}}$ & $2.10 \pm 0.15^{b}$ & $39.54 \pm 0.38^{b}$ \\
\hline D3 & $1.64 \pm 0.46$ & $20.69 \pm 0.32^{b}$ & $1161.4 \pm 27.3^{b}$ & $98.7 \pm 2.4^{\mathrm{a}}$ & $24.1 \pm 0.3^{\mathrm{ab}}$ & $0.79 \pm 0.28^{b}$ & $2.10 \pm 0.33^{b}$ & $39.43 \pm 0.51^{b}$ \\
\hline D4 & $1.67 \pm 0.42$ & $22.36 \pm 0.68^{\mathrm{a}}$ & $1238.9 \pm 22.5^{\mathrm{a}}$ & $98.8 \pm 2.6^{\mathrm{a}}$ & $25.3 \pm 0.6^{\mathrm{a}}$ & $0.82 \pm 0.39^{\mathrm{a}}$ & $2.17 \pm 0.16^{\mathrm{a}}$ & $40.96 \pm 0.14^{\mathrm{a}}$ \\
\hline D5 & $1.65 \pm 0.25$ & $19.92 \pm 0.74^{b}$ & $1107.1 \pm 26.4^{b}$ & $98.7 \pm 2.3^{\mathrm{a}}$ & $23.8 \pm 0.3^{b}$ & $0.77 \pm 0.39^{c}$ & $2.05 \pm 0.12^{b}$ & $38.59 \pm 0.24^{b}$ \\
\hline
\end{tabular}

Values in the same column with different superscript letters are significantly different $(p<0.05)$ from each other.

Table5. Apparent digestibility coefficient of Hybrid catfish fingerlings fed experimental diets for 70 days.

\begin{tabular}{|c|c|c|c|c|}
\hline Diet code & \multicolumn{2}{|c|}{ ADC of crude protein } & \multicolumn{2}{c|}{ ADC of crude lipid } \\
\hline D1 & $87.2 \pm 1.6$ & ${ }^{\mathrm{a}}$ & $82.4 \pm 1.5$ & ${ }^{\mathrm{a}}$ \\
\hline D2 & $87.3 \pm 2.3$ & ${ }^{\mathrm{a}}$ & $82.5 \pm 1.4$ & ${ }^{\mathrm{a}}$ \\
\hline D3 & $87.4 \pm 1.3$ & ${ }^{\mathrm{a}}$ & $82.6 \pm 2.3$ & ${ }^{\mathrm{a}}$ \\
\hline D4 & $87.5 \pm 1.7$ & ${ }^{\mathrm{a}}$ & $82.3 \pm 1.3$ & ${ }^{\mathrm{a}}$ \\
\hline D5 & $86.9 \pm 2.5$ & ${ }^{\mathrm{b}}$ & $81.4 \pm 1.2$ & ${ }^{\mathrm{b}}$ \\
\hline
\end{tabular}

International Journal of Innovative Studies in Aquatic Biology and Fisheries (IJISABF) $\quad$ Page | 26 
Growth Response and Haematological Indices of Hybrid Catfish Fingerlings Fed Varying Inclusion Levels of Fermented Sword Bean (Canavalia Gladiata) Seed Meal in a Concrete Tank

Values in the same column with different superscript letters are significantly different $(p<0.05)$ from each other.

Table6. Proximate composition analyses of whole-body Hybrid catfish (wet basis) fed experimental diets for 70 days

\begin{tabular}{|c|c|c|c|c|c|c|}
\hline \multirow{2}{*}{$\begin{array}{l}\text { Component } \\
(\%)\end{array}$} & \multirow[t]{2}{*}{ Initial } & \multicolumn{5}{|c|}{ Final $^{* 1}$} \\
\hline & & D1 & D2 & D3 & D4 & D5 \\
\hline Moisture & 77.6 & $74.9 \pm 0.3^{\mathrm{a}}$ & $74.4 \pm 0.6^{\mathrm{a}}$ & $73.2 \pm 0.8^{b}$ & $72.7 \pm 0.5^{\mathrm{c}}$ & $72.2 \pm 0.7^{\mathrm{c}}$ \\
\hline Protein & 14.9 & $18.4 \pm 1.3$ & $18.5 \pm 1.5$ & $18.5 \pm 1.7$ & $18.6 \pm 1.4$ & $18.5 \pm 1.6$ \\
\hline Lipid & 4.1 & $4.2 \pm 0.4^{\mathrm{c}}$ & $4.5 \pm 0.2^{\mathrm{c}}$ & $5.2 \pm 0.6^{b}$ & $6.2 \pm 0.4^{\mathrm{a}}$ & $6.8 \pm 0.5^{\mathrm{a}}$ \\
\hline Ash & 2.0 & $2.1 \pm 0.1$ & $2.3 \pm 0.3$ & $2.4 \pm 0.1$ & $2.4 \pm 0.3$ & $2.4 \pm 0.2$ \\
\hline
\end{tabular}

$* 1$ Values in the same row with different superscript letters are significantly different $(p<0.05)$ from each other $(n=3)$.

Table7. Haematological parameters of Hybrid catfish fingerling fed experimental diets for 70 days

\begin{tabular}{|c|c|c|c|c|c|c|c|c|c|c|c|}
\hline \multirow[t]{2}{*}{ Blood Parameter } & \multirow[t]{2}{*}{ Initial } & \multicolumn{7}{|c|}{ Final $^{* 1}$} & & \multirow{2}{*}{\multicolumn{2}{|c|}{ D5 }} \\
\hline & & D1 & & D2 & & D3 & & D4 & & & \\
\hline $\mathrm{PCV}(\%)$ & 20.36 & $32.46 \pm 1.84$ & $\bar{a}$ & $32.52 \pm 0.20$ & $\bar{a}$ & $32.58 \pm 0.44$ & $\mathrm{a}$ & $32.48 \pm 0.78$ & $\bar{a}$ & $31.88 \pm 0.44$ & \\
\hline WBC $\left(10^{3} \mathrm{~mm}\right)$ & 5.14 & $6.15 \pm 0.42$ & $\mathrm{~b}$ & $6.24 \pm 0.15$ & b & $6.35 \pm 0.26$ & $\mathrm{~b}$ & $6.47 \pm 0.38$ & b & $7.06 \pm 0.49$ & $\mathrm{a}$ \\
\hline $\operatorname{RBC}\left(10^{3} \mathrm{~mm}^{3}\right)$ & 1.94 & $3.16 \pm 0.06$ & $\mathrm{a}$ & $3.20 \pm 0.41$ & $\mathrm{a}$ & $3.18 \pm 0.32$ & $\mathrm{a}$ & $3.16 \pm 0.53$ & $\mathrm{a}$ & $3.04 \pm 0.22$ & $\mathrm{a}$ \\
\hline $\mathrm{Hb}(\mathrm{g} / 100 \mathrm{ml})$ & 6.04 & $9.97 \pm 0.57$ & a & $9.83 \pm 0.24$ & a & $9.80 \pm 0.45$ & $\bar{a}$ & $9.78 \pm 0.32$ & a & $9.57 \pm 0.51$ & $\mathrm{a}$ \\
\hline LYMPH(100) & 60.28 & $61.44 \pm 0.89$ & a & $61.69 \pm 0.66$ & $\mathrm{a}$ & $61.78 \pm 0.28$ & $\bar{a}$ & $61.85 \pm 0.77$ & $\mathrm{a}$ & $61.66 \pm 0.35$ & $\mathrm{a}$ \\
\hline $\mathrm{MCHC}(\%)$ & 29.67 & $30.72 \pm 0.65$ & $\mathrm{a}$ & $30.23 \pm 0.28$ & $\mathrm{a}$ & $30.08 \pm 0.36$ & a & $30.11 \pm 0.15$ & $\mathrm{a}$ & $30.02 \pm 0.34$ & $\mathrm{a}$ \\
\hline $\mathrm{MCH}(\mathrm{pg})$ & 31.13 & $31.55 \pm 0.44$ & $\mathrm{a}$ & $30.72 \pm 0.67$ & b & $30.82 \pm 0.11$ & D & $30.95 \pm 0.24$ & b & $31.48 \pm 0.36$ & $\mathrm{a}$ \\
\hline MCV (fl) & 104.95 & $102.71 \pm 0.82$ & $\mathrm{a}$ & $101.63 \pm 0.53$ & a & $102.45 \pm 0.62$ & $\bar{a}$ & $102.78 \pm 0.33$ & $\mathrm{a}$ & $104.87 \pm 0.41$ & $\bar{a}$ \\
\hline
\end{tabular}

PCV, packed cell volume; WBC, white blood cell; RBC, red blood cell; Hb, haemoglobin; LYMPH, lymphocyte;

MCHC, mean corpuscular haemoglobin concentration; MCH, mean corpuscular haemoglobin concentration;

$M C H$, mean corpuscular haemoglobin; $M C V$, mean corpuscular volume.

$* 1$ Values in the same row with different superscript letters are significantly different $(p<0.05)$ from each other $(n=3)$.

\section{DISCUSSION}

This study elucidates on the possibility of utilizing FCGSM in the diet of hybrid catfish Heteroclarias. The physio-chemical parameters of the water used for this experiment were within the acceptable and optimum range for the normal physiological functioning of African catfish fingerlings and catfish culture (Lazo and Davies, 2000; Anyanwu et al., 2012).

The crude protein and lipid composition of raw Canavalia gladiata seed used in this study were 28.61 and $9.44 \%$ respectively this was similar to those reported by Vadivel et al., 2010 but lower than the report of Abitogun and Oso (2014). In this study there was significant increase in the crude protein value and a slight decrease in the lipid values of the FCGSM (32.64\%) respectively when compared to the crude protein and lipid values of raw CGSM (28.61\%). This increase can be attributed to the fermentation technique used to process the CGSM. This agrees with the findings of Alegbeleye et al., (2012) Ogunji et al., (2014) Gatlin et al (2016), that fermentation processing technique improves and boost the protein component in legumes and other plant products.

There was a significant reduction in the anti- nutritional factors, tannin, phytate, oxalate and saponin in the FCGSM as compared to the RCGSM in this study; this is in agreement with works of Yigzaw et al., (2004), and Alegbeleye et al., (2012). They reported that fermentation can reduce toxic substances such as enzyme inhibitors, hemaglutinnins (lectin), phytates, polyphenols, flatulence factors, cyanogenic compounds, saponins, anti-vitamins, and allergens in plant products.

In this study, there was no feed rejection of any experimental diet during the feeding trial period, however the total feed intake, acceptability and utilization of the diets varies significantly among the treatment. Source and inclusion level of alternative ingredients especially plant protein-based ingredient in aquafeed production directly affects the palatability, acceptability and digestibility thereby having a significant impact on the growth performance and nutrient utilization of the fed fish ( Keremah et al., 2013). Weight gain and specific growth rate are usually considered as one of the most important measurement of productivity of diets (Omitoyin and Faturoti, 2000). The increase in weight gain reported in all the treatments indicated that the fish responded positively to all the diets 
and that the protein contents of the experimental diets adequately enhanced growth. In the current study, the growth performance of the hybrid catfish increased with the inclusion levels of the FCGSM and afterward showed a little decline even though it was not significantly different from the control diet this indicates the efficacy of FCGSM to be included in the diet up to $35 \%$ without any adverse effects on the fish growth. According to Oguji et al., (2008) feed utilization by fish are usually influenced by factors such as biological value of the feed and its nutrients. In this study the result of the feed utilization revealed that the experimental fishes were able to effectively utilize the nutrients in the diets as evident in the FE, PER and PR. These results are comparable to the works of Soluto 2010 and Mamam et al., 2013, and are in line with the findings of Ogunji et al., (2008) who reported that removal of undesirable components is essential for the enhancement and effective utilization of plant nutrients in fish feed.

The good haematological profile quality of fish fed FCGSM throughout the experimental period is an indication that fermentation significantly improved the quality of Canavalia gladiata seed meals. The improvement may be due to among other factors inactivation of some antinutritional factors present in FCGSM. Except for WBC of fish fed D5 which was slightly higher than the rest it was observed that the haematological parameters of the hybrid catfish fed FCGSM diets in this study were within the range as reported for hybrid catfish therefore conforms with the report of Tacon (1992). Report showed that nutritionally deficient diets cause decrease in haemaglobin concentration, reduced haematocrit and red blood cell count. Physiologically, haemoglobin is crucial to the survival of fish being directly related to the oxygen binding capacity of blood. In this study it was observed that red blood cell count (between 3.04-3.18 x 106 mm-3) and white blood cell count (between 6.15-7.06 x $103 \mathrm{~mm}-3$ ) and the haemoglobin values were between $9.57-9.97 \mathrm{~g} / 100 \mathrm{ml}$ ) hence may not have had a deleterious effect on hybrid catfish, given that the values were within the normal range reported for African catfish (Erondu et al., 1993; Musa and Omoregie, 1999).

Based on the growth performance, nutrient utilization and hematological indices of hybrid catfish fed FCGSM, this study reveals that fermentation is a good method for processing Canavalia gladiata bean seed and could be used to subdue the effect of the antinutritional factors (stressor) and thus improved haematological values. Further investigation to study the effect of the amino and fatty acid profile of the beans as it relates to fish feed need to be carry out.

\section{REFERENCES}

[1] AOAC., 1990. Official Method of Analysis. In: Association of Official Analytical Chemists, Helrich, K. (Ed.). 15th Edn., Arlington, Virginia, USA.

[2] Adeparusi, E.O. and A.D. Ajayi, 2000. Haematological characteristics of Nile Tilapia Oreochromis niloticus fed differently processed Lima bean (Phaseolus lunatus L.) diets. J. Agric. Technol., 2: 48-57.

[3] Adam, H.M. and H. Agab, 2008. Haematological and and resistance of channel catfish (Ictalurus biochemical indices of Clarias garipeinus collected punctatus) to Edwardsiella ictaluri challenge. from River Nile, Sudan. Sudan Academy of Sciences. Aquaculture, 185: 313-327. J., 2(1): 67-90.

[4] Akintayo, I.A., S.O. Obasa, W.O. Alegbeleye and A.M. Bangbose, 2008. Evaluation of toasted sunflower (Helianthus annus) seed meal in the diets of African catfish (Clarias gariepinus) fingerlings. Livestock Res. Rural Dev., Vol. 20.

[5] Akinwande, A.A., F.O. Moody, O.A. Sogbesan, A.A.A. Ugwumba and S.O. Ovie, 2004. Haematological response of Heterobranchus longifilis fed varying dietary protein levels. Proceedings of the 19th Annual Conference of the Fisheries Society of Nigeria, November 29-December 3, 2004, Ilorin, Nigeria, pp: 715718.

[6] Amusa, N.A., O.A. Ashaye and M.O. Oladapo, 2003. Biodeterioration of the African star apple (Chrysophylum albidum) in storage and the effect on its food value. Afr. J. Biotech., 2: 56-59.

[7] Anyanwu D C, Umeh O I, Ugo C K, Maduka B C and Mbachu M U 2012 Nutrient Utilization and Growth of Catfish (Clarias gariepinus) Fed Dietary Levels of Cassava Leaf Meal. Pakistan Journal of Nutrition 11 (11):1037-1040.

[8] A.O. Sotolu 2010 Growth Performance of Clarias gariepinus (Burchell, 1822) Fed Varying Inclusions of Leucaena leucocephala Seed Meal. Tropicultura, 28, 3, 168-172

[9] Blom, J.H., K.J. Lee, J. Rinchard, K. Dabrowski and J. Ottobre, 2001. Reproductive efficiency and maternal-offspring transfer of gossypol in rainbow trout (Oncorhynchus mykiss) fed diets containing cottonseed meal. J. Anim. Sci., 79: 1533-1539. 
[10] Clark, S., D.H. Whitmore Jr. and R.F. McMahon, 1979. Considerations of blood parameters of largemouth bass, Micropterus salmoides. J. Fish Biol., 14: 147-158.

[11] Dabrowski, K., K.J. Lee, J. Rinchard, A. Ciereszko, J.H. Blom and J.S. Ottobre, 2001. Gossypol Isomers bind specifically to blood plasma proteins and spermatozoa of rainbow trout fed diets containing cottonseed meal. Biochimica Biophysica Acta (BBA)-Gen. Subj., 1525: 37-42.

[12] Erondu, E.S., C. Nnubia and F.O. Nwadukwe, 1993. Haematological studies on four catfish species raised in freshwater ponds in Nigeria. J. Applied Ichthyol., 9: 250-256.

[13] Fagbenro, O.A. and O.T. Adebayo, 2005. A Review of the Animal and Aquafeed Industries in Nigeria. In: A Synthesis of the Formulated Animal and Aquafeed Industry in Sub-Saharan Africa, Moehl, J. and M. Halwart (Eds.). Food and Agriculture Organization of the United Nations, Rome, Italy, pp: 25-36.

[14] Fagbenro, O.A., C.O. Adedire, E.A. Owoseeni and E.O. Ayotunde, 1993. Studies on the biology and aquaculture potential of feral catfish Heterobranchus bidorsalis (Geoffroy St. Hilaire 1809) (Clariidae). Trop. Zool., 6: 67-79.

[15] Fagbenro, O.A., E.O. Adeparusi and W.A. Jimoh, 2010. Apparent nutrientdigestibility of sunflower andsesame seed meal in Clarias gariepinus (Burchell, 1822) fingerlings. Proceedingof he 25th Annual Conference of Fisheries Society of Nigeria, October 25-29, 2010, Badagry, Nigeria -

[16] Gaafar AY, El-Manakhly EM, Soliman MK, Soufy H, Mona SZ, Mohamed SG, Hassan SM (2010). Some pathological and hematological investigations on Nile tilipia (Oreochromis niloticus) following chronic exposure to edifenphos pesticide. J. Am. Sci. 6(10):542-551.

[17] George, F.O.A., S.O. Obasa and S.O. Otubusin, 2007. Growth response and carcass quality of African Catfish, Clarias gariepinus (Burchell, 1822) fed multi- enzyme-supplemented soybean meal diets. J. Applied Trop. Agric., 12: 51-59.

[18] Iwalewa, E.O., T.O. Idowu, M.A. Aderogba, B.A. Akinpelu and A.O. Ogundaini 2006. Biochemical and behavioural effects of eleagnine from Chrysophyllum albidum. J. Biol. Sci., 6: 1029-1034.

[19] Jimoh, W.A., 2012. Nutritive value of sesame (Sesamum indicum) or sunflower (Helianthus annuus) seed meals as dietary protein sources for African catfish. Ph.D. Thesis, Federal University of Technology, Akure.

[20] Jimoh, W. A., Aderolu, A. Z., Ayeloja, A. A., Shodamola, M. O. 2013 Replacement Value of Soybean Meal with Luffa cylindrical in Diet of Clarias gariepinus Fingerlings. International Journal of Applied Agricultural and Apicultural Research 9 (1\&2): 98-105

[21] Keremah R. I., Deekae S. N. and Akalokwu U. A 2013 Growth and Feed utilization of Catfish Hybrid (Heterobranchus longifilis x Clarias gariepinus) Fingerlings fed practical diets. Greener Journal of Agricultural Sciences Vol. 3(4), 286-290.

[22] Klontz, G.W. and "L.S. Smith (1968). Methods of using fish biological research subjects. In: Methods of Animal Experimentation (Ed. Gay, W.R). London: Academic Press.

[23] Lim, C., Klesius, P.H., Li, M.H. and Robinson, E.H. 2000. Interaction between dietary levels of iron and vitamin $\mathrm{C}$ on growth, hematology, immune response and resistance of channel catfish (I. punctatus) to E.challenge. Aquaculture, 185(3-4): 313-327.

[24] Mamman T, Ipinjolu JK, Magawata I. 2013 Hematological ondices of Clarias griepinus= $($ Burchell, 1882) fingerlings fed diet containing graded levels of calabash (Lagenaria vulgaries) seed meal. Journal of Biology, Agriculture and Healthcare.3:100-104.

[25] Olurin, K.B., E.A.A. Olojo and O.A. Olukoya, 2006. Growth of African catfish Clarias gariepinus fingerlings, fed different levels of cassava. World J. Zool.,1: 54-56.

[26] Osuigwe, D.I., A.I. Obiekezie and G.C. Onuoha, 2005. Some haematological changes in hybrid catfish (Heterobranchus longifilis x Clarias gariepinus) fed different dietary levels of raw and boiled jackbean (Canavalia ensiformis) seed meal. Afr. J. Biotechnol., 4: 1017-1021.Rastogi, S.C., 2007. Essentials of Animal Physiology. New Age International, New Delhi, ISBN-13: 9788122420142 , Pages: 578.

[27] Rinchard, J., K.J. Lee, S. Czesny, A. Ciereszko and K. Dabrowski, 2003. Effect of feeding cottonseed meal-containing diets to broodstock rainbow trout and their impact on the growth of their progenies. Aquaculture, 227:7-87.

[28] S.M. Hassan, 2010. Some pathological, biochemical exposed to cadmium chloride. Pollution Res., and hematological investigations on Nile tilapia 21(2): 119-131.

[29] Svobodova, Z., D. Pravda and J. Palackova, 1991. Unified Methods of Haematological Examination of Fish. Research Institute of Fish Culture and Hydrobiology, Vodnany, Czech Republic, Pages: 31. 
Growth Response and Haematological Indices of Hybrid Catfish Fingerlings Fed Varying Inclusion Levels of Fermented Sword Bean (Canavalia Gladiata) Seed Meal in a Concrete Tank

[30] Tacon, A.G.J., 1992. Nutritional fish pathology. Morphological signs of nutrient deficiency and toxicity in farmed fish. FAO Fish Technical Paper No. 330, Rome, pp: 75.

[31] Uys, W. and T. Hecht, 1985. Evaluation and preparation of a suitable dry feed and optimal feeding frequency for primary nursing of Clarias gariepinus larvae (Pisces: Clariidae). Aquaculture, 47: 173-183.

[32] Wedemeyer, G.A. and Yasutake W.T. (1977) Clinical Methods for the assessment of the effects of environmental stress on fish health. Technical papers of the U.S. fish wildlife service No 89. Washington DC. US Dept of the Interior Fish and Wildlife Service $18 \mathrm{p}$.

[33] Yue, Y.R. and Q.C. Zhou, 2008. Effect of replacing soybean meal with cottonseed meal on growth, feed utilization and hematological indexes for juvenile hybrid tilapia, Oreochromis niloticus x O. Aureus. Aquaculture, 284: 185-189.

Citation: G. G. Bake, et.al., "Growth Response and Haematological Indices of Hybrid Catfish Fingerlings Fed Varying Inclusion Levels of Fermented Sword Bean (Canavalia Gladiata) Seed Meal in a Concrete Tank". International Journal of Innovative Studies in Aquatic Biology and Fisheries, 5(2), pp.21-30. DOI: http://dx.doi.org/10.20431/2454-7670.0502004

Copyright: () 2019 Authors. This is an open-access article distributed under the terms of the Creative Commons Attribution License, which permits unrestricted use, distribution, and reproduction in any medium, provided the original author and source are credited. 